\title{
WHEN THE ADMINISTRATION PROMISES: PROTECTION OF LEGITIMATE EXPECTATIONS IN SERBIAN ADMINISTRATIVE PROCEDURE
}

Although the principle of legitimate expectations appeared in earlier drafts of the newest Serbian law on general administrative procedure, it was eventually downplayed to the level of guaranteeing predictability in administrative practice. The inclusion of the new principle was justified by harmonization of Serbian legislation with the principles of a common European Administrative Space. The contribution explores the notion of legitimate expectations in comparative law - ranging from so-called procedural to substantive expectations, with the possibility of contra legem effect of the principle. European administrative law scholars have long ago posed questions relating to the tension between the law and legal certainty and satisfying individual parties' (legitimate) expectations. Parties to administrative proceedings should, in line with the request for legal certainty, be aware of what type of action they can expect from the administration. On the other hand, life often necessitates changes in legislation and, even on occasions before that, adaptations to administrative behaviour. In comparative analysis, particular attention shall be paid to legislation and caselaw of the former Yugoslav states, since they share a history of common administrative legislation. The author aims to situate the Serbian version of this legal institute within the given range and, with an optimistic view to existent caselaw of the Constitutional Court, to point towards possibilities for its future implementation in the caselaw of the Administrative Court and in administrative practice.

Keywords: administrative procedure, legitimate expectations, predictability, legal certainty, good administration.

\section{INTRODUCTION}

The current Serbian Law on General Administrative Procedure (LGAP 2016) introduced the principle of predictability among its general principles (Article 5 para. 3), thus obliging

* Professor, Union University Law School (Belgrade, Serbia).E-mail: jelena.jerinic@pravnifakultet.rs, ORCID: https://orcid.org/0000-0002-3216-3635. 
the administration to respects its previous practice in identical or similar cases. It was envisaged as a corollary to the principle of legality (Davinić \& Cucić, 2021, p. 171). Does it, on the other hand, also provide a protection of legitimate expectations of parties to administrative proceedings created by such practice?

The notion of legitimate expectations first appeared in Serbian administrative-law circles in 2010, in the Ombudsman's Code of Good Practice (Zaštitnik građana, 2010), modeled on the European Code of Good Administrative Behavior. As a non-binding document, it appealed to civil servants "to respect the legitimate and reasonable expectations of citizens, in particular in the light of their previous caselaw". Also, they should refrain from creating "unrealistic and incorrect expectations [...] among conscientious citizens". ${ }^{160}$

In parallel, the term legitimate expectations appeared in 2011 and 2013 drafts of the LGAP (for genesis of the current LGAP, through four subsequent drafts, see Davinić \& Cucić, 2021). Both drafts proposed the protection of legitimate expectations of parties to administrative procedure as a new principle. According to them "the competent body [would be] obliged to act according to its earlier decisions in same or similar matters, unless it is justified and based on the law to act differently, which is to be specifically reasoned". ${ }^{161}$ It should be pointed out that the term legitimate expectations appeared here only in the article's rubrum.

The introduction of such a principle was justified by improvements to legal certainty and certainty of the parties, i.e. to settle and harmonize administrative practice, "with a dose of necessary and justified elasticity". ${ }^{162}$ The principle was also mentioned in the context of European principles of good administration, together with proportionality principle which was also defined by the proposed draft, as well as the later adopted LGAP 2016.

Finally, the adopted text of the LGAP 2016 settled for predictability as its principle, not explicitly mentioning legitimate expectations even in the provision's rubrum. It demands of authorities when acting in administrative matters to "take into account previous decisions made in the same or similar administrative matters" (Article 5 paragraph 3). Additionally, it requires of the authorities to provide a justification when they depart from their previous decisions in the same or similar matter (Article 141 paragraph 4).

\section{LEGITIMATE EXPECTATIONS IN ADMINISTRATIVE LAW OF EUROPEAN COUNTRIES}

Administrative law scholars have long ago started to analyze the tension between legal certainty and satisfying (legitimate) expectation of parties. The available literature in English is ample and rich.

\footnotetext{
${ }^{160}$ Rule 9 of the Code (Consistency and respect for justified expectations - Doslednost i poštovanje opravdanih očekivanja), similar to Article 10 of the European Code.

${ }^{161}$ Article 5 of the Draft LGAP from 2013, available in Serbian on the website of the then Ministry of Justice and Public Administration - titled "Nacrt zakona o opštem upravnom postupku - radna verzija" http://www. mpravde.gov.rs/sekcija/53/radne-verzije-propisa.php (8.9.2021).

${ }^{162}$ Rationale of the Draft LGAP also available at http://www.mpravde.gov.rs/sekcija/53/radne-verzije-propisa. php (4.11.2013.) under the title "Nacrt zakona o opštem upravnom postupku - obrazloženje".
} 
Legal certainty demands that parties know what kind of treatment they can expect in a specific administrative proceeding, or to quote Craig \& de Burca it is "a basic tenet of the rule of law that people ought to be able to plan their lives, secure in the knowledge of the legal consequences of their actions" (Craig \& de Burca, 2003, p. 380). In similar vein, Brown (2017, pp. 437-438) seeks to base the very idea of expectations in Bentham's doctrine of security. On the other hand, there are those who claim that constructing theories of legitimate expectation might not even be necessary, but that the focus should be transferred to "constructing an empirical account of the conditions and effects of legitimate expectations" (Tomlinson, 2020).

Nowadays, the principle exists in administrative laws of most European countries, but its content varies. In some jurisdictions, this discussion also encompasses the question whether it is possible to satisfy the parties' expectations based on administrative action which would, in the aim of passing a just decision, be contrary to current legal rules - the so-called contra legem effect of legitimate expectations, which truncates the once absolute supremacy of the legality principle, viewed in its narrow sense. However, there are also views that the administration actually creates by its actions a "non-legal, goal-dependent" rule, which legitimizes the generation of expectations in that way (Perry \& Ahmed, 2014).

Even though there are competing positions on the best justification for the principle of legitimate expectations (Craig, 2015, p. 142), in general, as defined by scholars, it demands that administrative authorities if that is all possible, fulfil the legitimate expectations created by them (Berge \& Widdershoven, 1998, pp. 423-424).

Besides administrative action in individual cases, legitimate expectations can be created by general legal acts, laws and other regulations, which raises questions about retroactive application of laws and withdrawal of individual decisions. The principle of legitimate expectations is thus in an unbreakable bond with the principle of legal certainty and is often presented as one of its aspects or emergent forms (Berge \& Widdershoven, 1998, p. 424).

The German Constitutional Court, which considers legal certainty as a general principle of law, also made this deduction (Koopmans, 2003, p. 66). The citizens should know what their legal position is, but also to be able to rely on expectations created according to statements and actions of the executive. If the authorities have created an impression that they will follow a certain policy, they cannot decide otherwise, damaging the citizen who had good reason to believe that his or her case would be decided according to earlier practice.

Further on, the principle has a procedural and a substantive aspect. When first recognized in some jurisdictions, it was viewed solely as a procedural guarantee (e.g. in the context of natural justice in the United Kingdom (UK), see Forsyth, 1988, p. 240). Nowadays, the legitimate expectations created give rise not only to a procedural guarantee of some form (such as, right to a hearing), but can lead to a substantial decision, obliging the administrative authority to act in a particular direction. Additionally, some commentators see a possible third aspect - the so-called compensational protection of legitimate expectations, whereas the party received compensation of expenses incurred due to expectations created by the administration (Šikić \& Ofak, 2011, p. 140).

As mentioned, an important question arising in respect of this principle is the possibility of its contra legem effect. Even though, traditionally, the principle of legality has been 
considered as supreme in administrative procedure and as such, obligatory at all times, there are jurisdictions which acknowledge the possibility of such a contra legem effect in caselaw. Alongside Dutch jurisprudence, Belgian commentators also recognize that the so-called principle of good faith (which encompass the protection of legitimate expectations) can have such an effect, if it prevails in the balancing (Lust, 2002, pp. 31-32). It is seen as part of general principles of justice, as basic norms of any legal system, i.e. are part of constitutional matter. That makes them equal to the principle of legality and not subordinate to it, so the legality principle cannot a priori prevail, but is necessary to weigh both interests in a particular case.

All this does not lead to expectations caused by administrative actions being fulfilled in each case - a weighing of interests is necessary. This aspect also differentiates legitimate expectations from the concept of vested rights (also a tenet of legal certainty), because vested rights have a more absolute position and cannot be overridden by public interest (Thomas, 2000, pp. 45-46).

The principle of legitimate expectations was primarily developed in caselaw, although its aspects have found their way into legislation. Germany and the Netherlands are considered frontrunners in that respect, since in the middle of the $20^{\text {th }}$ century, they were the only ones in Europe to have developed this principle.

For example, in German caselaw, legitimate expectations were raised in cases of withdrawal or revocation of administrative acts (Zuruecknahme und Widerruf von Verwaltungsakten), where protection of legality was first seen as the deciding argument, with the principle of legitimate expectations later included in the weighing exercise. The first such case was decided by the Federal Administrative Court in 1959, later leading to introduction of the principle of legitimate expectations to the Administrative Procedure Act (Kunnecke, 2006, pp. 125-126). Articles 48 and 49 of the Administrative Procedure Act, inter alia, deal with situations in which a party had relied on an unlawful administrative act, with regard to the public interest, as well as the (financial) disadvantage to the person affected. It was the German jurisprudence that later influenced the imbedding of this principle in European Union (EU) administrative law (Craig, 2015, p. 342).

On the other hand, even though it was created through caselaw, this principle was not included in the Dutch General Administrative Law Act (GALA) - codification of administrative law, as a general principle and remained a mainly unwritten principle (Peeters, 2005, pp. 57-58). This is justified by the fact that these cases often involve a "subtle process of necessary weighing of different interest which, as such, is not suitable for regulation by rigid legal norms" (Berge \& Widdershoven, 1998). As it eventually boils down to evaluation of circumstances of an individual case, the courts' role is crucial. In the Dutch GALA, the principle appears only in relation to subsidies (Division 4.2.6, Article 4:51 GALA). According to the established caselaw in the Netherlands, legitimate expectations can be created by laws, decisions, publication of policy rules and guidelines, provision of information on application of law or promises, contracts, court judgements (Berge \& Widdershoven, 1998).

In British caselaw the phrase legitimate expectations was first used in 1969 to describe "something less than a right which may nevertheless be protected by principles of natural 
justice" (Parpworth, 2008, p. 319). The Belgian State Council, as its supreme administrative court, in the late 1980s, included the principle of legitimate expectations into the principle of legal certainty, since the party has the right to rely on the established practice or policy of the administration (Popelier, 2000, p. 327).

Within the EU, its courts have drawn several principles from the national legal systems, including this one, and developed it further, including them within the corpus of "general principles common to the laws of the Member States" (Koopmans, 2003, p. 88). However, some claim that the meaning of the principle within EU law is narrower than in some of its member states (e.g. according to Addink, 2002, it cannot have a contra legem effect). Even though it first appeared in the Algera case before the European Court of Justice (ECJ) in 1957 (Widdershoven, 2005, pp. 3-5), the EU jurisprudence on this principle "took off" during the 1970s (Craig, 2015, p. 339) and was later developed further. Therefore, during the 1990s, it was recognized that legitimate expectations could be raised even by soft-law, policy instruments, such as guidelines and notices, as well as by a course of conduct or assurances given by the administration (Craig \& de Burca, 2003, pp. 380-387). Further on, the ECJ allowed legitimate expectations to have both procedural and substantive impact, resulting in individuals to whom loss was caused by a change in policy receiving the substantial benefit they sought "in the absence of any overriding public interest to the contrary” (Craig \& de Burca, 2003, p. 386).

Of particular relevance here is the caselaw of the Court of Justice of European Union (CJEU) regarding withdrawal of formal European Commission decisions. The caselaw differentiates between lawful and unlawful decisions and between favourable decisions or the ones conferring rights or benefits and non-favourable decisions. The differentiation is relevant since, for example, when lawful beneficial decisions are withdrawn, the beneficiaries are likely to have increased legitimate expectations and the withdrawal should be allowed only under restrictive conditions (Craig, et al., 2017, pp. 136-137).

In addition, the EU caselaw had a feedback effect on the member states' jurisprudence, as well (e.g. according to Millet this happened in Great Britain in the 1990s and later on (Millet, 2002, p. 320). As Craig clams, the UK courts accepted "that EU administrative law precepts, such as proportionality and legitimate expectations, must be applied by UK courts in challenges via judicial review that involve EU law" (Craig, 2015, p. 289). In some other cases, general principles of EU law made their way to member states' legislations, such as the Italian APA containing "a renvoi" to the principles, such as due process, proportionality, and legitimate expectations" (Craig, et al., 2017, pp. 17-18), since the principle did not previously exist in Italian law (Chiti, 1995). However, some scholars have shown that the incorporation of the principle into national legal systems does not automatically lead to its interpretation in conformity with the CJEU - some countries have accepted it only in EU-related cases, while in other the incorporation is full and involves the domestic framework, as well (Boymans \& Eliantonio, 2013).

As mentioned above, the principle appeared in the 2002 European Ombudsman's Code of Good Administrative Behaviour (Article 10), subdivided into three aspects: the need for consistency in administrative behaviour; the rest of "legitimate and reasonable expectations that members of the public have in light of how the institution has acted in the past"; and 
the duty to advise the public on how to pursue a particular administrative matter.

The model rules of the Research Network on EU Administrative Law (ReNEUAL) list the principle alongside other prominent principles listed in its preamble, and presents it in conjunction with the principle of consistency (Craig, et al., 2017, p. 40). Similar to German law, the principle is further dealt with in relation to rectification and withdrawal of decisions, in Chapter 6 of the model rules, basically attempting to codify the existing caselaw of the CJEU, and is in part inspired by member states' law (Craig, et al., 2017, pp. 136-137).

In countries which entered the EU since the 2000s, it seems that introduction of the principle ensued more as a result of influence of the so-called European administrative space than the caselaw of their own courts (e.g. on the Czech Republic see Frumarová, 2021, pp. 117-118). There are also those in which neither law, nor jurisprudence recognise the posssibility to protect legitimate expectations in administrative law (e.g. for Poland, see Parchomiuk, 2017, pp. 18-21).

\subsection{A view over the fence: Legitimate expectations in laws on the territory of former Socialist Federal Republic of Yugoslavia}

Once part of the same administrative space, all former Yugoslav territories reformed their general administrative procedure after acquiring independence - starting with Slovenia in 1999 (Kovač, 2013) to Serbia, which closed the circle in 2016. Some received outside support of foreign experts, who tried to convey into the legislative texts some of the principles and experiences of senior members of the EU (e.g. see Koprić \& Đulabić, 2009 and Davinić \& Cucić, 2021 on cases of Croatia and Serbia).

In most of these laws (e.g. Slovenia, Croatia, Bosnia and Herzegovina, and North Macedonia), the principle of legitimate expectations - in any of its forms - is not expressly guaranteed among principles of general administrative procedure (for North Macedonia, see (Pavlovska-Daneva \& Davitkovska, 2017, str. 274-277), although in some countries, it can be construed from other provisions of their general administrative procedure acts (GAPA) - e.g. in Croatia (Articles 103 and 155 of the GAPA), and is recognized as such in caselaw.

Laws in Montenegro, Serbia and Kosovo do recognize it as one of their general principles, titled either as the principle of predictability (Serbia and Kosovo, Article 8) or of legitimate expectations (Montenegro, GAPA, Article 5 paragraph 2, as a component of the principle of legality). In substance, these provisions limit themselves to the duty of the administration to respect its earlier established caselaw, while failing to establish a specific right of the parties to call upon their expectations legitimately created by such caselaw.

However, more importantly, the principle has been recognized in the caselaw of the courts in only a few of these countries. In Croatia, both the Constitutional Court and Administrative Court have, since the early 2000s, recognized the principle, either explicitly or implicitly and both as a procedural and material guarantee (Šikić \& Ofak, 2011, pp. 137-139; Vezmar Barlek, 2011, pp. 575-578). In the given cases, the parties' legitimate expectations were acknowledged when created either by previously applicable regulations 
or by final administrative acts. The courts demanded that the expectations be legitimate and reasonable and in each case a balancing against the public interest was performed.

\section{SERBIAN CASELAW}

As said above, from 2011 to 2016 and in the final text of the GAPA, the principle of legitimate expectations came from having "its own article" to being a part of the legality principle and labelled as predictability in administrative practice. In the very wording of the norm, which is now less harsh, we travelled from a strict obligation to follow its earlier practice (unless it is justified and based on law to act differently), to a duty to "take care" of earlier decisions passed in the same or similar administrative matters.

It is worth noting that even in the earlier drafts, in the very provisions there was no mention of legitimate or any other expectations (the notion just appeared in the rubrum). Formulated in this way, the principle was only directed towards unification of administrative practice, which was later downplayed by the formulation in the adopted LGAP 2016. There is every chance that the interpretation of the norm would go along these lines and not towards the protection of legitimate expectations of the party created by administrative practice.

In that view, one could argue that the notion is not novel to Serbian administrative law, since the administration already had an obligation to act consistently and this was covered by existing principles in GAPAs all through the Yugoslav period. Some Serbian scholars went as far as to deem it unnecessary (Milkov \& Radošević, 2020). That position can be accepted, if for no other reason than for reasons of "betrayed" expectations created not so rarely in Serbian administrative practice. Solely for the purpose of illustration, we shall use two similar cases from the Netherlands and Serbia - which occurred 40 years apart.

In 1979, a man in the Netherlands, relying on information given to him by the tax authorities over the phone, reported a certain category of extraordinary expenses as a tax expense. However, the tax inspector did not recognize that as an expense, to the detriment of the party. The Dutch Supreme Court found that the risk of misinformation should regularly be borne by the taxpayer, because otherwise the government would have been hindered in their duty to provide information (Berge \& Widdershoven, 1998, p. 446). However, in special cases, the tax authorities may be bound by the information provided. This will be the case when the information is not obviously contrary to the law and if the interested party suffers damage. And if it is phrased as a promise, the tax authorities will be easier to be bound by the given information. The information provided by the taxpayer in order to obtain such a promise must be accurate as well as the promise should not be manifestly contrary to law.

In 2020 in Serbia, tens of people who earn their income working "on the internet" and basically receiving income from abroad, claimed that they have previously (over the previous five years) been orally informed by tax officials that they do not have to report the income and pay the accompanying taxes, inter alia, because tax decisions are never issued, especially for small amounts. This Tax Administration later utilize their legal authority to determine tax obligation for the period of five years back. After mass protests, the Government "gave 
in" and agreed to amend the underlying legislation to allow for some concessions to the taxpayers, but the principle of legality prevailed, with no regard to created expectations.

Of course, it would be an exaggeration to expect the Serbian Tax Administration to develop an innovative approach towards the created expectations and balance those against the obvious public interest of regular and ample tax collection, particularly in absence of guidance towards that by the judiciary, as offered to their Dutch counterparts. Nevertheless, it can be concluded that this innovative approach viewed in isolation would constitute the most promising solution.

Does this mean that Serbian administrators and administrative adjudicators have to start from the very basics? The current text of the LGAP 2016, as well as its interpretation in caselaw, gives rise to creation of legitimate expectations only by administrative acts, i.e. the parties to administrative proceeding are to be able to rely on the previous practice of the administrative authorities in same or similar issues. A logical question which could follow from this would probably be - how would one (especially a layperson) go about to learn about established administrative practice?

On the other hand, caselaw on the application of the predictability principle from Article 5 of the LGAP 2016 is scarce, or even negligible. It should be added that caselaw on the application of general principles of the LGAP 2016 (even the earlier laws) is very modest. Judgements in administrative disputes rarely apply these provisions directly, let alone their further or more extensive interpretation. The LGAP 2016 is seen as a comprehensive codification of procedural rules, leaving little room from judicial activism.

In a rare example, the Administrative Court focused solely on the procedural aspects of predictability. Finding that the administrative authority has deviated from its earlier practice, the Court annulled the decision because the authority failed to add a justification for the deviation. (Judgement of Administrative Court No. 9 y 3278/19, 2019). In all probability, if a paragraph was added in the decision's rationale, that would satisfy the requirement, without delving into expectations possibly created on the party's side. In a previous case, where the party claimed a breach of the predictability principle, the Court did not delve into that, since it found that the LGAP 2016, which contains it, was not yet in force when the case at hand occurred (Judgement of the Administartive Court, No. 12 Y 18623/17, 2018). That pictorially speaks of the Court's willingness to indulge in judicial activism.

As there is little caselaw, there is also little scholarly analysis of the principle's application, other than general and theoretical overview of the LGAP's provisions already referenced in this text. Some notice has been given to potential difficulties of its adequate application on the local government level, i.e. of the challenges of unification of administrative practice on the local level on which all local government units independently apply the same laws. This is because the LGAP 2016 does not oblige administrative authorities simply to follow its own practice, but to follow the practice in "same or similar matters", which in the case of local government competences is shared by all local government units.

Measuring of performance in the application of good governance principles in 2018 showed that one of the lowest scored indicators was exactly predictability (Jerinić, et al., 2020 , p. 279). Efforts have been undertaken by the national local government association to standardize administrative procedures and views of contributing to unification of practice. 
Some scholars see chances for improvement in increasing transparency and publishing administrative inspection reports which control the LGAP's application in all administrative authorities (Vučetić, 2021, pp. 181-198). On the other hand, even though not expressly mentioned in the present (nor previous) LGAP 2016, legitimate expectations are a known concept in the caselaw of the Ombudsman, as well as of the Serbian Constitutional Court, in several of its decisions which concern review of administrative action.

Since 2011, the Ombudsman has, in its annual reports, recognized the breach of legitimate expectations as one of the most common violations of the right to good administration. In that very year, it singled out an example in which the Tax Administration, by a change in its interpretation of the tax laws, wronged a number of individual farmers who took maternity leave. The Tax Administration refused to act upon the Ombudsman's recommendation and annul their decisions, after which the Government stepped in and covered the costs of taxes of the farmer who have not previously paid the taxes levied according to the controversial interpretation. Still, the ones who have paid the taxes were left without compensation (Protector of Citizens, 2011, pp. 133-134). The following year, the law was amended, once again demonstrating the indisputable primacy of the principle of legality in the eyes of the Serbian administration.

Since then, every annual report contains at least one significant case singled out in the Ombudsman's annual reports in which legitimate expectations of citizens were created by either administration or the legislature - e.g. in 2014 regarding changes of the Law on Road Safety and the ensuing replacement of driving licenses (Protector of Citizens, 2015, pp. 161-162); in 2019 in relation to untimely decisions and erroneous interpretation of laws by the Real Estate Cadastre (Protector of Citizens, 2020, pp. 94-95); in 2020 towards the City of Belgrade concerning a water supply break down (Protector of Citizens, 2021, pp. 114-115) - while the overall annual statistics usually showed over a 100 or 200 individual complaints alleging unfulfilled expectations.

The Constitutional Court found on at least four occasions, between 2013 and 2019, and decided in favour of complainants which called upon their legitimate expectations created by final administrative acts (relating to land usage and building and construction). Interestingly enough, the Constitutional Court did not base its decisions on the provisions of the LGAP 2016, on its principle of legality or other principles. It founded its decisions on constitutional complaints on constitutional guarantees of the right to property and corresponding caselaw of the European Court of Human Rights on Article 1 Protocol 1 to the European Convention on Human Rights, which finds such legitimate expectations part of one's property (Decision of the Constitutional Court [CC], Už 412/2011, 2013; Decision of the CC, Už 6763/2011, 2014; Decision of the CC, Už 8782/2015, 2018 \& Decision of the CC, Už 1783/2017, 2019).

\section{CONCLUSIONS}

In this very initial research, the aim was to determine the position of Serbian GALA within the wider European circle. In respect of Serbian legislation on general administrative procedure, it was mainly a normative analysis, compared to the basic perception of this 
principle in European legislatures and caselaw, without going into the nuances of caseto-case considerations in different jurisdictions. This is also due to the fact that Serbian caselaw on application of the new LGAP's predictability principle is practically non-existent and, so far, the principle remained a "letter on paper".

On the other hand, the express recognition of legitimate expectations appears in the decisions of other state bodies, namely the Ombudsman and the Constitutional Court, from as far as 2011, but this apparently had no visible impact neither on the drafting of the LGAP nor the caselaw of the Administrative Court. Therefore, legitimate expectations are far from a novel, or even unnecessary concept in the Serbian legal system.

As defined today, the predictability principle, even though it appeared in the rubrum of the provision in earlier 2011 and 2013 LGAP drafts, is not directed towards the protection of legitimate expectations - procedural or substantive - but it is settled for remaining an incentive for unification of administrative practice. That alone is an important task, which in its turn could also contribute to eventual establishment of the principle of legitimate expectations. So far, the predictability principle has not stretched to the protection of legitimate expectations.

Even without express recognition in the LGAP 2016, the very recognition of the principle by the Constitutional Court, similar to the Croatian example, could eventually lead to changes in Administrative Court's caselaw and administrative practice, in particular if similar cases against administrative authorities and the Administrative Court itself keep appearing before the Constitutional Court. This would mean that the principle actually springs out of caselaw rather than legislation, which, truth be told has not been a feature of Serbian caselaw thus far. 


\section{LIST OF REFERENCES}

Addink, G. H., 2002. From Principles of Proper Administration to Principles of Good Governance: Good Governance-Lessons from National Administrative Law for the European Law. In: Paper for the IUS Seminar on Good Governance. s.l.:s.n., pp. 12-22. Berge, G. \& Widdershoven, R., 1998. The principle of legitimate expectations in Dutch constitutional and administrative law. The Hague, The Hague: Intersentia.

Boymans, P. \& Eliantonio, M., 2013. Europeanization of Legal Principles? The Influence of the CJEU'S Case Law on the Principle of Legitimate Expectations in the Netherlands and the United Kingdom. European Public Law, 19(4), p. 715-738.

Brown, A., 2017. A Theory of Legitimate Expectations. The Journal of Political Philosophy, 25(4), p. 435-460.

Chiti, M., 1995. Are there Universal Principles of Good Governance?. European Public Law, 1(2), p. $241-258$.

Craig, P., 2015. UK, EU and global administrative law: Foundations and challenges. Cambridge: Cambridge University Press.

Craig, P. \& de Burca, G., 2003. EU Law - texts, cases and materials. 3rd Edition ed. Oxford: Oxford University Press.

Craig, P., Hofmann, H., Schneider, J. \& Zill, J., 2017. ReNEUAL model rules on EU administrative procedure. Oxford: Oxford University Press.

Davinić, M. \& Cucić, V., 2021. Europeanization of General Administrative Procedure in Serbia. Review of Central and East European Law, 46(2), pp. 153-178.

Decision of the Constitutional Court Už 1783/2017 (2019).

Decision of the Constitutional Court Už 6763/2011 (2014).

Decision of the Constitutional Court Už 8782/2015 (2018).

Decision of the Constitutional Court, Už 412/2011 (2013).

Forsyth, C. F., 1988. The Provenance and Protection of Legitimate Expectations. The Cambridge Law Journal, 47 (2), pp. 238-260.

Frumarová, K., 2021. Czech Republic. In: Z. Kmieciak, ed. Administrative Proceedings in the Habsburg Succession Countries. Lodz \& Warszawa: Łódź University Press \& Wolters Kluwer Polska sp. z o.o., pp. 107-128.

Jerinić, J., Vučetić, D. \& Stanković, M., 2020. Priručnik za sprovođenje principa dobrog upravljanja na lokalnom nivou. Belgrade: Standing Conference of Towns and Municipalities.

Judgement of Administrative Court No. 9 y 3278/19 (2019).

Judgement of the Administartive Court, No. 12 Y 18623/17 (2018).

Koopmans, T., 2003. Courts and political institutions: a comparative view. Cambridge: Cambridge University Press.

Koprić, I. \& Đulabić, V., 2009. Modernizacija općeg upravnog postupka i javne uprave u Hrvastkoj. Zagreb: Institut za javnu upravu.

Kovač, P., 2013. Modernizing Administrative Procedural Law in Slovenia as a Driving Force of Efficient and Good Administration. NISPAcee Journal of Public Administration and Policy, 4(2), pp. 39-66. 
Kunnecke, M., 2006. Tradition and Change in Administrative Law: An Anglo-German Comparison. Berlin: Springer.

Lust, S., 2002. Administrative Law in Belgium. In: R. Seerden \& F. Stroink, eds. Administrative Law of the European Union, its Member States and the United States. A comparative analysis. Antwerpen - Groningen: Intersentia.

Milkov, D. \& Radošević, R., 2020. Načelo predvidivosti u upravnom postupku. Zbornik radova Pravnog fakulteta u Novom Sadu, Issue 1, pp. 1-19.

Millet, P., 2002. The rights to good administration in European law. Public Law, Issue summer. Parchomiuk, J., 2017. The Protection of Legitimate Expectations in Administrative Law: A Horizontal Perspective. Baltic Journal of Law \& Politics, 10(2), pp. 1-25.

Parpworth, N., 2008. Constitutional and Administrative Law. 5th Edition ed. Oxford: Oxford University Press.

Pavlovska-Daneva, A. \& Davitkovska, E., 2017. The Macedonian General Administrative Procedure Act: Between Tradition and Modernization. Hrvatska i komparativna javna uprava, 17(2), pp. 263-290.

Peeters, M., 2005. The Concept of Precaution as Shaped by the Courts. In: F. A. M. S. E. V. D. L. Frits Stroink, ed. Judicial Lawmaking and Administrative Law. s.l.:Intersentia nv, pp. 57-80.

Perry, A. \& Ahmed, F., 2014. The coherence of the doctrine of legitimate expectations. The Cambridge Law Journal, 73(1), pp. 61-85.

Popelier, P., 2000. Legal Certainty and Principles of Proper Law Making. European Journal of Law Reform, 2(3), pp. 321-342.

Protector of Citizens, 2011. 2011 Annual Report, Belgrade: Protector of Citizens of the Republic of Serbia.

Protector of Citizens, 2015. Regular Annual Report of the Protector of Citizens for 2014, Belgrade: Protector of Citizens of the Republic of Serbia.

Protector of Citizens, 2020. Regular Annual Report of the Protector of Citizens for 2019, Belgrade: Protector of Citizens of the Republic of Serbia.

Protector of Citizens, 2021. Regular annual report of the Protector of Citizens for 2020, Belgrade: Protector of Citizens of the Republic of Serbia.

Seerden, R. \& Stroink, F., 2002. Administrative Law in the Netherlands. In: Administrative Law of the European Union, Its Member States and the United States: A Comparative Analysis. Antwerpen - Groningen: Intersentia.

Šikić, M. \& Ofak, L., 2011. Nova načela upravnog postupka (s posebnim naglaskom na razmjernost, legitimna očekivanja i stečena prava). Zbornik Pravnog fakulteta u Rijeci, 32(1), pp. 127-153.

Thomas, R., 2000. Legitimate Expectations and Proportionality in Administrative Law. Portland: Hart Publishing.

Tomlinson, J., 2020. Do we need a theory of legitimate expectations?. Legal Studies, pp. 1-15. Vezmar Barlek, I., 2011. Primjena načela legitimnih očekivanja u praksi Upravnog suda Republike Hrvatske. Zbornik Pravnog fakulteta Sveučilišta u Rijeci, 32(1), pp. 569-579. Vučetić, D., 2021. Serbia. In: Z. Kmieciak, ed. Administrative Proceedings in the Habsburg Succession Countries. Lodz and Warszawa: Łódź University Press and Wolters Kluwer Polska. 
Widdershoven, R., 2005. The principle of loyal cooperation, lawmaking by the European Court of Justice and the Dutch courts . In: F. Stroink \& E. v. d. Linden, eds. Judicial Lawmaking and Administrative Law. Mortsel, Belgium: Intersentia NV, pp. 3-35. Zaštitnik građana, 2010. Predlog kodeksa dobre uprave. Belgrade: s.n. 